\title{
Model Dan Bentuk Kepemimpinan Dalam Islam
}

\author{
Mochamad Mukhlis \\ UIN Maulana Malik Ibrahim Malang
}

\begin{abstract}
ABSTRAKS
Islam adalah agama kaffah yang mengatur segala aspek kehidupan, temasuk kepemimpinan, dikarenakan dengan adanya imamah ini aspek kesejahteraan, falah dan keadilan dalam suatu Negara dalam skala besar dan amanah yang melekat pada individu akan tertata secara sempurna. Tulisan ini dimaksudkan untuk memberi gambaran singkat tentang praktik, bentuk, pola dari kepemimpinan yang ada dengan dikaitkan dengan pola kepemimpinan Rasulullah Muhammad Saw. Berdasarkan sejumlah pandangan dapat diambil kesimpulan awal bahwa, pola kepemimpinan Rasulullah sangat pas dan relefan untuk diterapkan disegala dimensi kehidupan. Dan pola kepemimpina yang dicontohkan Rasulullah syamil dan kamil.
\end{abstract}

Kata Kunci : Imamah, Khilafah, Shahibul Amr 


\section{PENDAHULUAN}

Berbicara Pemimpin pasti tidak akan ada habisnya. Dikarenakan kita sendiri adalah pemimpin secara sunnatulloh. Walaupun secara skala kecil dalam keluarga semisal kita adalah pemimpin dalam keluarga tentunya sesuai dengan kapasitas kita. Lebih detail lagi kita adalah pemimpin dari anggota tubuh kita, dan kita haruslah pandai, arif, bijak dan amanah dalam mengelola menggerakan dan memanagemen seluruh anggota tubuh kita shingga pada kita tidak ada ruang sedikitpun untuk khiyanat terahadap amanah kita.

Dewasa ini terjadi ambigu tentang arti pemimpin, apa pegertian imamah, khilafah, dan shahibul amr. Serta ruang lingkup kepemimpinan. Belum lagi tentang jenis atau tipologi kepemimpinan yang terjadi dan bahkan tereduksi oleh masyarakat.

Sebenarnya kita memliliki contoh panglima perang yang handal yakni Nabi Muhammad Saw. Setiap orang harus mengetahui kemampuan dan keterbatasan orang lain dan menggunakan pengetahuannya dalam memperoleh dan meminta bantuan ${ }^{1}$, dan beliau sangat paham tentang karakter masing - masing orang.

Bentuk pengejawantahan Imam ada 3 yakni (1). Imamah (2). Khilafah (3). Shahibul amr

1. Imamah

a. Definisi menurut etimologi

Imamah menurut etimologi adalah bentuk masdar dari kata kerja “ Amma” yang artinya mendahului mereka. Sedangkan al imam ialah setiap oang yang diikuti, seperti pemimpin yang lain.

Ibnu Manzhur menjelaskan "Al Imam ialah setiap orang yang iikuti oleh suatu kaum, baik mereka yang berada dalam jalan yang lurus ataupun sesat. ${ }^{2}$

Imam juga berarti contoh artinya sesuatu yang dijadikan contoh. Al- imam juga berarti benang yang dibentangkan diatas bangunan, lalu menjadi acuan untuk mendirikan bangunan sehingga sisinya menjadi sama.

b. Definisi menurut Terminologi

Menurut tokoh

1. Al Mawardi mendefinisikan imamah itu ditetapkan untuk menggantikan tugas kenabian dalam menjaga agama dan menata dunia dengan agama.

2. Imam Haramain Al Juwaini mendefinisikan Imamah adalah kepemimpinan sempurna yang berkaitan dengan kalangan khusus maupun umum dalam berbagai persoalan agama maupun dunia.

3. An-Nafasi, Imamah adalah wakil Rasululloh dalam urusan menegakkan agama yang wajib diikuti oleh seluruh umat.

\footnotetext{
${ }^{1}$ Afzalur Rahman, Nabi Muhmmad sebagai Seorang Pemimpin Militer, (Jakarta, AMZAH, 2002) hal,63.

${ }^{2}$ Abdullah Ad-Dumaiji, Konsep Kepemimpinan dalam Islam, (Jakarta Timur: Ummul Qurra,2016) hal. 37.
} 
4. Ibnu Khaldun mendefinisikan imamah adalah mengatur seluruh umat berdasarkan pandangan syariat dalam mewujudkan maslahat-maslahat mereka yang bersifat ukhrawi dan dunia yang akan kembali kepada ukhrawi.

c. Definisi menurut Alquran

1. Terdapat dalam al-quran surat Al-Baqoroh 124

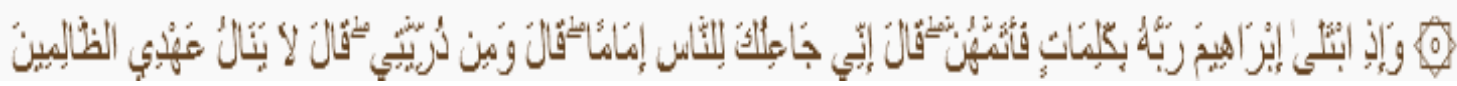

\section{Artinya :}

Dan ketika Kami menjadikan Baitullah itu) yakni Kakbah (sebagai tempat kembali bagi manusia) maksudnya tempat berkumpul dari segenap pelosok (dan tempat yang aman) maksudnya aman dari penganiayaan dan serangan yang sering terjadi di tempat lain. Sebagai contohnya pernah seseorang menemukan pembunuh bapaknya, tetapi ia tidak mau membalas dendam di tempat ini, (dan jadikanlah) hai manusia (sebagian makam Ibrahim) yakni batu tempat berdirinya Nabi Ibrahim a.s. ketika membangun Baitullah (sebagai tempat salat) yaitu dengan mengerjakan salat sunah tawaf di belakangnya. Menurut satu qiraat dibaca 'wattakhadzuu' yang artinya, dan mereka menjadikan; hingga menjadi kalimat berita. (Dan telah Kami perintahkan kepada Ibrahim dan Ismail) (yang bunyinya)("Bersihkanlah rumah-Ku) dari berhala (untuk orang-orang yang tawaf, yang iktikaf) artinya yang bermukim di sana (orang-orang yang rukuk dan orang-orang yang sujud!") artinya orang-orang yang salat

2. Terdapat dalam al-quran surat al - furqan 74

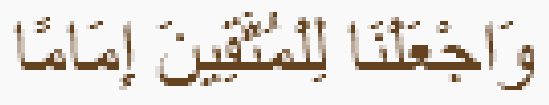

Artinya dan jadikanlah kami pemimpin bagi orang-orang yang bertaqwa.

Magsudnya adalah menjadi pemimpin yang diikuti oleh orang-orang setelah kami. ${ }^{3}$

3. Terdapat dalam al-quran surat al anbiya' 73

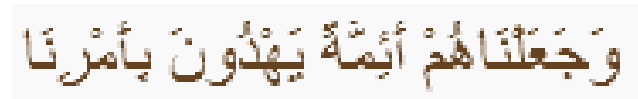

Artinya :

Kami telah menjadikan mereka itu sebagian pemimpin-pemimpin) dapat dibaca Aimmatan atau Ayimmatan, yakni pemimpin yang menjadi teladan dalam kebaikan (yang memberi petunjuk) kepada manusia (dengan perintah Kami).

\footnotetext{
${ }^{3}$ Tafsir At-Thabari (kairo,XIX)hal. 52.
} 
Maksudnya adalah pemimpin - pemimpin yang diikuti dalam hal kebaikan danketaatan kepada allah dengan mengerjakan perintah dan menjauhi larangannya.

d. Definisi menurut Al-hadist

"Kullukum Roin wamas "ulun anroiyatihi" artinya, setiap indifidu dari kita adalah pemimpin dan akan dimintai pertanggungan jawab.

2. Khilafah

Khilafah menurut arti bahasanya adalah pengganti dan orang yang menggantikan pekerjaan orang lain saat orang yang digantikan berhalangan atau meninggal dunia. ${ }^{4}$ Setelah Rasululloh wafat orang yang bertugas mengatur kebijakan bagi kaum muslimin bagi urusan - urusan kaum muslimin seperti Abu Bakar, Umar, Usman dan Ali.

Sedikit terjadi perbedaan mencolok tentang arti imamah dan khalifah, jika imamah cenderung sakral sebab imamah menjurus pada suri keteladanan dan pemimpin.

3. Shahibul Amr

Shahibul Amr kata yang dinisbatkan bagi imam. Menurut Muhammad bin Ishaq umumnya kaum muhajirin dan Anshar sepeninggal Rasululloh menjuluki Ali sebagai shahibul amr. Amr berarti pemerintah yakni seorang yang memiliki wewenang untuk berkuasa, memerintah dan melarang. Quran an-nisa 59

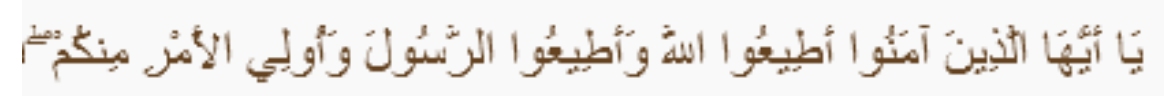

Artinya:

Hai orang-orang yang beriman taatilah Allah dan taati Rasul dan Ulul Amr diantara kalian.

\section{PEMBAHASAN}

1. Proses kepemimpinan

a. Kepemimpinan dalam organisasi

Adapun fungsi dari pemimpin menjadikan administrator dan manager

a). Fungsi administrator ada 2 hal pengambil keputusan dan perumus kebijakan

i. Pengambil keputusan

○ Tepat dan dapat memecahkan masalah yang dihadapi

- Cepat jangan kadaluarsa sehingga merugiakan organisasi

- Praktis yakni dapat dilaksanakan sesuai kemampuan

○ Rasional yakni keputusan yang diambil dapat diterima akal sehat

○ Mudah untuk dicapai

ii. Perumus kebijakan

\footnotetext{
${ }^{4}$ Ibrahim Amini, Para Pemimpin Teladan , ( Jakarta, Al-Huda, 2005) hal. 18.
} 
- Berdasar pada penelitian yang objektif didukung dengan data

- Isi dantujuan kebijakan tidak bertentangan dengan sasaran

○ Hasil musyawarah

○ Peristiwa yang sama harus dengan kebijakan yang sama

b). Fungsi manager
a. Organisator
b. Pengarah
c. Pengawas
d. Penilai

b. Kepemimpinan dalam perubahan sosial

Perubahan pada masyarakat merupakan keniscayan namun pada akhir - akhir ini peruahan dimasyarakat sangatlah cepat. Faktor yang mempenggaruhi perubahan tersebut antara lain:

- Kontak dengan kebudayaan lain

- Sistempendidikan yang maju

- Sikap menghargai hasilkarya orang lain dan keinginan maju

- Terlalu toleran terhadap perubahan yang menyimpang

- Sistemmasyarakat yang terbuka

- Penduduk yang heterogen

- Ketidak puasan masyarakat

- Orientasi kedepan

- Meningkatnya taraf hidup

2. Tipologi kepemimpinan

1. Kepemimpinan tradisional

Kepemimpinan yang lahir dimasyarakat primitive atau masyarakat yang baru tumbuh

2. Kepemimpinan kharismatik

Kepemimpinan ini timbul karena pemimpin tersebut memiliki kemampuan scara psikis danmental serta kemampuan tertentu seingga apayang diperintahkan akan dituruti oleh pengikutnya. Biasanya menggunakan gaya persuasive danedukatif.

3. Kepemimpinan Rasional

Kepemimpinan dalam organisasi akanefektif jika kepemimpinannya itu dapat diterima oleh pengikutnya secara rasional secara dua arah dapat dibenarkan oleh sipemimpin dan pengikutnya. Pemimpin melihat sesuatu secara obyektif.

4. Kepemimpinan otoriter 
Nama lainya otokratis yang biasanya tidak bertahan lama.

5. Kepemimpinan demokratis

Kepemimpinan ini memiliki ciri:

a. Menempatkanmanusia dalam pandangan terhormat

b. Senantiasa berusaha mempertautkan antar kepentingan dan tujuan organisasi

c. Terbuka menerima kritik

d. Menciptakan iklim yang kondusif mengutamakan kerjasama yang kompak.

e. Mendorong bawahan untuk bebas berinisiatif

f. Senantiasa mebina diri untuk biasa berkembang.

6. Kepemimpinan Tunggal

Dapat diklasifikasikan menjadi dua:

a. Pimpinan (leadership)

a). Bertindak sebagai organisator dankoordinator

b). Bertanggung jawab terhadap kelompok yang dipimpin

c). Merupakan bagian dari kelompoknya

d). Kekuasaan berasal dari kepercayaan anggota

e). Dipilih dan diangkat atas kemauan / persetuuan anggota

b. Kepala (headership)

a). Bertindak sebagai penguasa

b). Bertanggung jawab terhadap atasan

c). Takselalu merupakan bagian dari kelompoknya

d). Kekuasaan berpijak pada peraturan

e). Tidak dipilih melainkan diangkat.

\section{Kepemimpinan kolektif}

Mengandung pengertian bersama. Secara luas kepemimpinan tidak dijalankan oleh orang perorangan dalam kapasitas apa saja. Yang menonjol adalah kebersamaan baik dalam merencanakan program, melaksanakan kegiatan maupun dalam memberikan penilaian.

3. Kepemimpinan dalam islam

Menurut konsep islam yang dirumuskan alquran ada 5 syarat

a. Beriman dan bertaqwa ( QS. Al - A'raf : 96)

b. Berilmu pengetahuan ( QS. Al - Mujadilah : 11)

c. Mempunyai perncanaan dan evaluasi ( QS. Al Al-Hasyr : 18)

d. Mempunyai kekuatan mental melaksanakan kegiatan ( QS. Al - Baqoroh: 147 ) 
e. Mempunyai kesadaran dan tanggung jawab moral serta menerima kritik ( QS. As- shaf :2-3)

4. Model kepemimpinan Rasululloh

a. Aqidah, hal ini diawali dengan membina aqidah menanamkan keesaan terhadap Allah dan kecintaan kepada Rasulnya. Dicatat dalam tempo23 tahun telah berhasil membentuk struktur masyarakat yang stabil dan dinamis.

b. Suri tauladan, belia mencontohkan kepada para sahabat apa arti konsisten dan bagaimana konsisten itu, yang biasa kita sebut istiqomah. Belia berkata jujur dan mencontohkan kejujuran.

c. Sistem kaderisasi dimana Rasululloh mengkader sahabatnya dengan sabar, disiplin sehingga terbentuk sahabat yang militan seperti khulafaurrasyidun.

d. Musyawarah, pola inilah yang dibuat oleh rasul dalam mengambil keputusan.

5. Kepemimpinan dakwah

Pola kepemimpinan Rasululloh sangat identik dengan ajakan bukan paksaan. Hal ini tercermin dalam alquran dalam QS Ali Imran 110

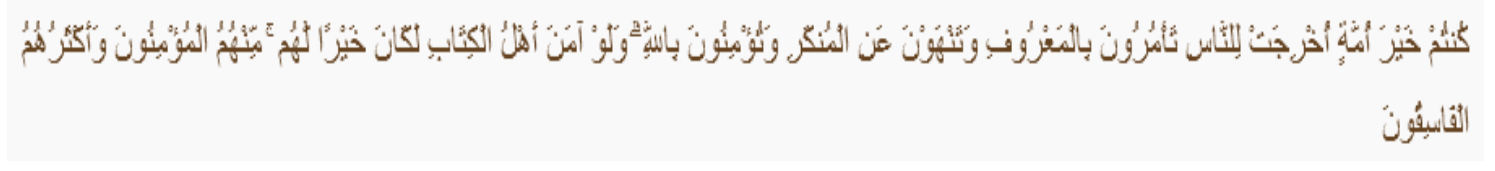

Artinya:

(Adalah kamu) hai umat Muhammad dalam ilmu Allah swt. (sebaik-baik umat yang dikeluarkan) yang ditampilkan(buat manusia, menyuruh kepada yang makruf dan melarang dari yang mungkar serta beriman kepada Allah. Sekiranya Ahli Kitab beriman, adalah ia) yakni keimanan itu (lebih baik bagi mereka. Di antara mereka ada yang beriman) misalnya Abdullah bin Salam r.a. dan sahabat-sahabatnya (tetapi kebanyakan mereka orang-orang yang fasik) kafir.

Adapun sasaran kepemimpinan Dakwah Rasulullah diklasifikasikan pada tiga komponen yakni:
a. Sumber daya manusia
b. Organisasi atau lembaga dakwah
c. Program dan strategi

6. Konsep diri dalam kepemimpinan

Ada beberapa tipologi manusia

a. Manusia ekonomis

b. Manusia teoritis

c. Manusia estetis 

d. Manusia religis
e. Manusia berkuasa
f. Manusia sosialis

7. Kepemimpinan dalam komunikasi

Dalam hal ini Rasululloh selalu berperan:

a. Mengutamakan pelaksanaan tugas

b. Bertenggang rasa

c. Membangkitkan kepercayaan (inpirasi)

d. Penghargaan dan pengakuan

e. Partisipasi pengambilan keputusan

f. Memberikan otonomi dan delegasi

g. Menetapkan tugas

h. Training

i. Pemecahan masalah

j. Mengendalikan konflik

Kepemimpinan yang dilaksanakan Nabi Muhammad merupakan bentuk praktek nyata dari pelaksanaan Al-Quran secara murni. Terbukti 4 pilar yang rosultanamkandalamkepemimpinan antara lain
1. Sidiq
2. Amanah
3. Tablig
4. Fatonah

Dewasa ini banyak pemimpin ada yang sidiq tapi tidak amanah, ada yang fatonah tetapi belum sidik bahkan tidak tabligh.

Masih terdapat dimasyarakat pola kepemimpinan pejabat, bukan manajer. Masih terlihat pola pada kepemimpinan pejabat ABS (asal bapak senang) masih belum dilandasi profesionalitas. Seharus nya pola yang perlu dikembangkan di masyarakat Indonesia adalah pejabat yang manajer, sehingga dapat berkolaborasi dalam pencapain tugas yakni adanya tujuan / Goal, rasa berkhidmat untuk yang lain dalam menjalankan tugas memimpin.

Penulis menyebut kepemimpinan di dalam islam adalah kepemimpinan dakwah dimana setiap individu berkewajiban mengajak (dakwah) mempengaruhi orang lain untuk berada pada pola yang falah dan maslahah. Disaping itu pola kepemimpinan dalam islam adalah kepemimpinan jihad dimana tiap invidu berkewajiban berjihad yakni mengalahkan hawa nafsu menuju mardhotillah. Dalam islam kepemimpinan adalah sebagai amanah sebagai contoh, orang yang tidak amanah merupakan ciri dari sifat munafik. 
Adakalanya dalam kepemimpinan itu harus otoriter dengan melihat sekeliling kita semisal lingkungan kita acuh, adanya konflik yang berkepanjangan dan pemimpin memandang perlu mengambil kebijakan secara otoriter untuk mengamankan lingkungannya. Yang perlu di kembangkan adalah menggabungkan kepemimpinan kharismatik, kepemimpinan rasional, kepemimpinan demokratis, kepemimpinan kolektif. Tentunya juga melihat situasi, letak demografis, serta aspek lain.

Penulis sepakat sebelum kepemimpinan terbentuk yang perlu di bekali oleh calon pemimpin adalah aqidah uluhiyah / rububiyah, jika aqidah ini kuat maka filter terhadap pengaruh negative akan termampatkan. Disamping itu pola kepemimpinan akhlak perlu dikembangkan karena apa yang dilakukan oleh pemimpin akan diikuti bahkan akan dinilai oleh bawahannya. Dan hal ini menjadi modal bagi pemimpin tidak hanya pandai beretorika tapi juga pandai dalam berakasi. Hal ini dilakukan oleh sahabat Rasululloh Umar bin khatab, sang khalifah berjalan disepanjang malam, menelusuri lorong - lorong sempit menghirup nuansa kehidupan rakyatnya, ia tidak segan berdialog dengan rakyat didepan rumah, dipinggir jalan atau masjid guna mencari masukan tentang apa yang mesti ia lakukan untuk mensejahterakan mereka ${ }^{5}$.

Keberhasilan kepemimpinan adalah membentuk jiwa individu berkekuatn spiritual (al Tawhid/ aqidah), ber keagungan akhlaq (al akhlaq) berkeluasan ilmu pngetahuan (al-ilm), kematangan profesioanal (al-Itqan) dan berkemampuan membangun silaturahmi (networking/ Sillat al rahim) ${ }^{6}$.

\section{KESIMPULAN}

Bertolak dari uraian diatas bahwa jika kita ingin membangun pola kepemimpinan harus menggunakan figur yang haqqul yaqin Amm. Dan yang pantas menjadi figur yakni nabi Muhammad. Beliau dalam etos kerja selalu melihat :

1. Selalu menyingkronkan tujuan kepemimpinan dun-ya wal ukhrawi

2. Menjadikan semua hal menyenangkan dan kekeluargaan

3. Tidak menjaga jarak dengan siapapun

4. Menganggap bawahan sebagai sahabat bukan mesin dan memberi penghargaan

5. Memupuk potensi sahabat agar menjadi mujahid, hamluda'wah yang militansi

6. Menanamkan hidup adalah perjuangan " innamaal "usri yusra”

7. Memotifasi dan mengedukasi

8. The right man on the right place ${ }^{7}$. Selalu menempatkan sesuatu pada kadarnya.

9. Syurga dan mardhotillah sebagai tujuan utama.

\footnotetext{
${ }^{5}$ Heri Muhamamad, 44 Teladan Kepemimpinan Muhammad ( Jakarta: GIP, 2008) hal,13

${ }^{6}$ Muhammad Djakfar, Wacana Teologi Ekonomi(Malang, UIN-Pres, 2015)Hal, 252

${ }^{7}$ Khatib Pahlawan Kayo, Kepemimpinan Islam dan dakwah (jakarta, AMZAH,2005) hal, 36.
} 
Model Dan Bentuk Kepemimpinan Dalam Islam

Dalam kepemimpinan juga harus memperhatikan aspek maslah wal mursalah yakni mengambil manfaat dan menolak madharat (bahaya) ${ }^{8}$

${ }^{8}$ Yuliar D Sanrego ismail, Falsafah Ekonomi Islam (Jakarta, Karya Abadi, 205) hal, 129. 
Model Dan Bentuk Kepemimpinan Dalam Islam

\section{REFERENSI}

Ad-Dumaiji Abdullah, Konsep Kepemimpinan dalam Islam, Jakarta Timur: Ummul Qurra,2016

Amini Ibrahim , Para Pemimpin Teladan, Jakarta, Al-Huda, 2005

Djakfar Muhammad, Wacana Teologi Ekonomi, Malang, UIN-Pres, 2015

D Sanrego Ismail Yuliar, Falsafah Ekonomi Islam,Jakarta, Karya Abadi, 2005

Muhamamad Heri, 44 Teladan Kepemimpinan Muhammad, Jakarta: GIP, 2008

Pahlawan Kayo Khatib, Kepemimpinan Islam dan dakwah, Jakarta, AMZAH,2005

Rahman Afzalur, Nabi Muhmmad sebagai Seorang Pemimpin Militer, Jakarta, AMZAH, 2002

Tafsir At-Thabari , Kairo,XIX 